\title{
Using Authentic Materials for Extensive Reading to Promote English Proficiency
}

\author{
Siao-cing Guo ${ }^{1}$ \\ ${ }^{1}$ Department of Applied Foreign Languages, National Taipei College of Business, Taiwan \\ Correspondence: Siao-cing Guo, Department of Applied Foreign Languages, National Taipei College of \\ Business, Taipei 100, Taiwan, ROC. Tel: 886-2-2322-6418. E-mail: schu@webmail.ntcb.edu.tw
}

Received: April 22, 2012 Accepted: May 21, 2012 Online Published: July 11, 2012

doi:10.5539/elt.v5n8p196 URL: http://dx.doi.org/10.5539/elt.v5n8p196

\begin{abstract}
Current literature points to the importance and benefits of extensive reading. Extensive reading provides contextualized clues for better reading comprehension (Krashen, 1982), and substantial linguistic input (Bell, 1998) needed for language development. Several studies have found a correlation between extensive reading and specific linguistic skills including breadth of reading choices, improved writing skills, ease in oral communication, and improvement in other aspects of language. Literature already incorporates much simplified reading material that would encourage even beginners to engage in extensive reading; however, there has been insufficient research to explore the effects of extensive reading that utilizes authentic materials. Krashen (2011) specifies a crucial need for continuous research in this area in support of the inclusion of extensive reading in the EFL curriculum. Thus, this researcher attempted to add to the literature by investigating the impact of authentic materials as the main source of extensive reading. This quantitative study employed a pre- and post-test design using a simulated English proficiency test and an attitudinal survey. Other data such as course exams and students' class participation records were also included to increase validity. This study intended to discover the effects of extensive reading using online materials on students' language proficiency, and students' attitudes toward the extensive reading activity. The study results indicated a strong relationship between extensive reading and vocabulary development. Students thought that extensive reading also enhanced their overall English ability and knowledge.
\end{abstract}

Keywords: extensive reading, authentic materials, vocabulary acquisition

\section{Introduction}

It is a general belief that students need to receive extensive input to develop their language proficiency. The language input EFL students receive is mostly from the classroom. Students do not often take any initiative to locate foreign language resources outside of class or engage in reading beyond a course requirement. Educators attribute the decline of students' reading engagement to the advent of multimedia (Li \& Renganathan, 2008). In recent years, classroom teaching and research has increasingly focused on extensive reading. Researchers such as Day and Bamford (2008) and Hunter (2009) have identified a significant impact of reading on academic achievement. Reading can empower students with extensive vocabulary, syntax, and other language expertise that will enrich their use in the target language. Hence, teachers play an important role in providing sufficient reading materials for students. This study is a sequel study to a previous investigation on an eight-week extensive reading program using graded readers by this researcher in 2010 . The previous study involved fifty college students for the exploration of students' reading habits and preferences, and eleven students for a study of reading speed as a result of extensive reading. The finding revealed that extensive reading using simplified materials has proven to enhance students' reading habits, reading speed, and vocabulary knowledge. Most importantly, students received tremendous pleasure from reading these selections, at the same time they were able to nurture their intrinsic motivation for continuous reading. The previous findings support the practice of extensive reading in the development of English proficiency and autonomous learning. However, that study left unanswered another question: Will exposure to different literary texts have similar effects on language development? Therefore, in this present study this researcher sought to find out whether a different source of texts would also generate a positive effect on language acquisition as graded readers did. The researcher intended to probe the relationship between extended reading on authentic materials and language proficiency as well as 
other potential effects influenced by authentic reading.

\section{Literature Review}

Students today have become more passive and reluctant in regard to reading, doing no more than what's required. Educators are concerned about students' disinterest and, therefore, are endeavoring to find ways and sources to encourage students to read. Textbooks are widely adopted in classroom teaching because they cater to specific language needs and gradual mastery of language skills (Wang, Lin, \& Lee, 2011). But perhaps because textbooks materials often break down language to discrete linguistic points, it may be too formulaic for students. "While [textbook] materials provide valuable information to learners, students seem to have little interest in them" (Guo, 2011); hence, the source for English learning does not need to be limited to a specific set of textbooks and practices (Griffiths \& Keohane, 2000), and Widdowson (1990) suggests the incorporation of authentic materials for learners.

\subsection{Authentic Reading}

After a careful review of literature, I find that Gilmore's definition of authentic materials is similar to Morrow's (1977, cited by Gilmore, p. 98), both claiming that authentic materials contain 'real language, produced by a real speaker or writer for a real audience and designed to convey a real message of some sort'. The texts generally produced by native speakers could be comprehended rather effortlessly by native speakers. Gilmore also points out that authentic materials had been used for language learning several decades ago and have regained their popularity due to the rise of the communicative approach (Gilmore, 2007). The goal of the communicative approach is to develop language competence for communication in real life. Textbooks are often written with classroom dialogue practices that are artificial, thus presenting a gap from real life language. But, unfortunately, with perhaps inadequate understanding of the method, some instructors have not recognized the value of using authentic materials.

The use of authentic materials has been strongly debated because of its complexity in vocabulary and structures especially for lower-level learners. But Baleghizadeh's study (2010) showed that the concerns could be overcome by adequate assistance. The experimental study involved 90 Iranian students in three groups: simplified text, unsimplified text, and unsimplified texts using an interactive approach with teacher's facilitation. The findings demonstrate that reading with a negotiation process in which students could ask questions about difficult words and text significantly outperformed the other groups, even the group that read simplified texts. The opportunity to interact with the teacher was proven to be more effective than linguistic simplicity alone. Baleghizadeh's study justified the incorporation of authentic reading materials as long as it was accompanied by the teachers' facilitation because the argument of linguistic complexity interfering with comprehension can be easily resolved by teachers' facilitation and students' interaction with teachers. Krashen (1982) also weighs in that the contextualized clues can assist students in comprehending the text and provide extra linguistic information. Students will pick up word usage, collocation, and syntax while reading. Purcell-Gates, Duke, \& Martineau (2007) discovered positive effects from their large longitudinal study with 420 students receiving different degrees of authenticity in literary texts and activities that were carefully monitored. They concluded that more significant growth occurred in the members of the group that utilized texts with greater authenticity than occurred in the group whose texts had less authenticity. After practicing teaching with authentic materials for more than a decade, C. Kelly, L. Kelly, Offner, and Vorland (2002) ascertain that real-life materials energize the class and create positive feelings about learning. They complement classroom teaching well. The positive feelings can increase students' interest and intrinsic motivation for learning.

Authentic materials are believed to generate greater interest among teachers, students and even publishers than do traditionally structured materials (Gilmore, 2007). The wide variety of authentic materials ranges from literature, CDs, DVDs, news, movies, TV programs, even to brochures and menus. Floris (2008) points out the necessity for incorporating authentic materials in the course design because they are more motivating, and engaging, and relevant to students' lives. Other researchers claim that authentic materials provide opportunities for language use in a more relevant and communicative way (Sánchez, Pèrex, \& Gómes, 2010). Huang (2005) states the importance of authentic materials, because when at an adequate level they elevate learners' sensitivity to and competence in the language. Littlewood (1992) brings attention to several considerations in the adoption of authentic materials: learners' needs, their interest in topics, language situations and functions students would find useful (see also Gilmore, 2007). Nunan (1999) also suggests giving students their own choice of materials and the incorporation of student-produced materials as another component of authentic texts.

The utilization of authentic materials from online resources is particularly valuable. Taiwan, which exists in an EFL context, lacks sufficient access to authentic materials and opportunities for English interaction. This lack 
was identified as a major obstacle for Taiwan English learners ( $\mathrm{Wu}, 2009)$ and is very likely the same for students in other EFL contexts as well. Yu (2006) utilized articles from The New York Times to promote cadets' English due to the limited exposure of her subjects to authentic materials. Yu discovered positive effects of authentic materials on group discussions as well as presentations. She also found improvement in vocabulary and verbal expressions, a better understanding of cultures, and higher motivation. Bahrani and Sim (2011) also found the positive effects of extensive exposure to particular universal news from mass media on the speaking ability of 90 Iranian university students. These authentic materials from various media connect students with the real world and keep them informed as well as keep their attention on task. These materials although authentic at their origin can be directly used or adopted as different instructional methods or for different purposes.

\subsection{Extensive Reading}

Both common sense and research have shown evidence that students improve their reading by reading. Copious studies already exist in support of extensive reading (Krashion, 2004; Pikulski \& Chard, 2005; Silva, 2009; Therrien, 2004). By extensive reading, it is meant that students read for a significant amount of time. It is an approach beyond skill development; an activity students "[choose] to do for a variety of personal, social, or academic reasons (Day \& Bamford, 2000, p. 4). Susser and Robb (1991) agree. They claim that extensive reading involves reading a large variety of materials for general understanding and usually obtaining pleasure from reading. Extensive reading materials provide substantial linguistic input (Bell, 1998), which is needed for language acquisition. Thus, extensive reading provides a rich source for developing learners' linguistic competences. Researchers point out the importance of extensive reading, but what does extensive reading entail? Successful extensive reading requires the following (adapted from Maley's list, 2009).

1. Reading often and in a large quantity

2. Reading in a wide variety of topics and genres

3. Reading content that is interesting and compelling

4. Reading books students themselves select

5. Reading for pleasure and information

6. Reading is its own reward

7. Reading at levels appropriate for the readers

8. Reading speed is fast, not slow

Many studies have shown that extensive reading has positive effects on a variety of students' language skills. Anderson, Wilson, and Fielding (1988) found a correlation between extensive reading and reading ability among children, and a study by Greenberg, Rodrigo, Berry, Brinck, and Joseph (2006) attained similar results with adult learners. Lee's study (2008) with children in Taiwan on sustained silent reading reveals that the longer students read, the better the reading results.

\subsection{Reading and Vocabulary}

Reading aids the acquisition of new vocabulary and helps retain prior learned vocabulary. Vocabulary plays a vital role in students' comprehension and acquisition of a foreign language. Without an adequate number of words, language learners will not be able to comprehend or use the second language (L2). Researchers argue that vocabulary is the foundation of other skills, a core component of language development (Kazerooni, Saeedi, \& Parvaresh, 2011). Min and Hsu (2008) assure the importance of vocabulary on reading comprehension and advocate the use of extensive reading along with direct instructions on vocabulary. Laufer's studies (1992) consistently point to a minimum of 3000 word families required for comprehending an unsimplified text; a native speaker beginning high school has approximately 5000 word families (Hsueh-Chao \& Nation, 2000). Clearly, vocabulary is the key to a basic understanding of the target language. According to Richard Day, one of the primary ways to learn vocabulary is through reading (2011). Reading can serve as a means for vocabulary development because it brings students into contact with new words and repeatedly reinforces the words previously known.

Several studies have identified a strong correlation between extensive reading and increased vocabulary. Soltani (2011) divided 80 Iranian intermediate-level students into a control group and an experimental group for an experimental study. Both groups received the same instruction methods and materials, except the experimental group read an additional five short stories over ten weeks. The pre- and post-test results showed a significant gain in vocabulary in the experimental group but not in the control group. Ponniah's experimental study (2011) with 49 undergraduate students also reinforces the conclusion that exposure to texts is a much more effective 
way to acquire vocabulary than conscious vocabulary learning. Moreover, Golkar and Yamini (2007) found vocabulary highly correlated with reading comprehension and proficiency level. These studies confirm that a considerable amount of exposure to L2 texts is necessary to increase vocabulary knowledge and reading comprehension.

\subsection{Reading and Other Language Competence}

Extensive reading presents vocabulary in breadth and depth and allows students an access to an advanced vocabulary that students will likely encounter in academic texts (Cummins, 2008). In addition to vocabulary gain, extensive reading has consistently been proven to increase other competences. Wang (2006) discovered the significant impact extensive reading training has on the communicative competence of college students. Studies by Hsu and Lee (2007) and Smith (2007) with college students in Taiwan also found positive effects of reading on writing. Huebner concludes that students who were involved in enhanced reading programs outperformed students not only in reading related skills but also in other academic achievements. Following their extensive program, Greenberg, Rodrigo, Berry, Brinck, and Joseph (2006) unveiled their findings that the more learners read, the more confident they become. McNeil's study with South Korean students manifested extensive reading enhancement not only in overall language competences but also in their motivation for continuous reading. Extensive reading clearly aids first- and second-language acquisition and fosters positive attitudes toward language learning.

Earlier as well as recent literature on reading literacy emphasizes the importance of reading extensively. While textbooks and instructions are valuable and necessary in developing specific skills, it is essential for language learners to be exposed to as much of the target language as possible. If students have experience with only textbooks materials, they will have difficulty in comprehending the texts that address real contexts, as Nunan (1999) stated in his book based on his empirical practices. The Internet reading assigned for an English class in this study was intended to encourage students to read more substantially and extensively. The incorporation of the Internet materials was allowed because of easy access and adaptability, and the wide topicality available on the World Wide Web, as proposed by Teeler and Gray (2000). Students were encouraged to read individually at home and discuss it in class with the teacher's assistance and facilitation. Drawing from the literature review and personal experience with extensive reading as instructional or learning practices, the researcher has observed numerous benefits from repeated exposure to print. The previous study by this researcher found positive relationships between graded readers and a boost in both language acquisition and motivation. Leading researchers such as Grabe (2004) and Krashen (2011) assert the importance for continuous research in extensive reading in support of its inclusion in classroom practice. Chen (2007) further identified the need to conduct more reading research in EFL contexts. For that reason, the researcher carried out a study on the effects of graded readers in the previous year and furthered the research on the use of authentic materials to facilitate learning in this present study.

\section{Methodology}

This study was intended to investigate the effects of extensive reading using authentic materials on students' English proficiency particularly with regard to vocabulary and grammar. For this study, three main questions were addressed.

1. Does extensive reading of authentic materials have an effect on vocabulary gain?

2. Does extensive reading of authentic materials have an effect on improvement of grammar?

3. Does extensive reading of authentic materials have an effect on other language skills?

\subsection{Participants}

The researcher recruited around fifty students from two intact classes to participate in this extensive reading experiment. The recruited students from a five-year college in Taiwan were English majors in their fourth year of study -the equivalent to freshmen from a regular university. These students were evenly assigned to two classes based on their entrance exam scores when they entered the college; therefore, they should have been at a similar level as they started college. However, the entrance exam took place more than four years ago; thus, a pre-test was devised to determine if the students from the two classes were still at a similar level. The two classes were then randomly assigned to be an experimental group and a control group. All students received the same classroom instructions, with the only difference being that the experimental group was given supplementary materials related to course topics for extensive reading outside of class.

\subsection{The Instruments}

The treatment for the experiment was a set of 10 online reading materials related to the course topics given to 
students in the experimental group over a period of three months. As Tran (2007) suggests, teachers can select materials that are at a suitable level and can be read at a manageable time to help students with their reading skills. Of course students can also select the reading materials that they feel comfortable with, but for the study purpose and convenience, the instructor selected readings for students in the experimental group. The main instrument for this study was an English proficiency test, a simulated TOEIC test with a vocabulary and a grammar session, 25 items each. Students' test results on vocabulary from their midterm and final were collected for the comparison with the results from the English proficiency test. An opinion survey on extensive outside reading was created to better understand students' thoughts and attitudes about the outside reading. The survey contained 19 questions, among which nine were on studying and leisure habits and 10 on extended reading materials. The questionnaire and the simplified English proficiency test were reviewed by two other English teachers for face validity. The researcher/instructor also closely observed students' vocabulary usage and participation during class time.

\subsection{Procedures}

Two classes of the fourth-year English majors from a Five-year College were recruited for the study. Two classes were randomly assigned to an experimental group and a control group. The pre-test was administered to both groups at the beginning of the spring semester in 2011. During the semester, students received the same course instructions and took the same midterm and final examinations. Close to the end of the semester, both groups of students were given the post-test, the same English proficiency test that was given at the beginning of the term. Toward the end of the term, the questionnaire was administered to both student groups. The researcher assured the participants that any tests, or survey data and results from the study would be kept confidential and used for research purposes only, and that the test results or their feedback would not affect their grades in any way.

After the collection of the tests, the test results were analyzed using SPSS. Descriptive statistics with the reading survey was calculated. Inferential statistic analysis was also performed to find out the relationship between extensive reading and vocabulary and grammar.

\section{Results from Language Proficiency Test}

After approximately three months, the pre- and post-test results of the simulated TOEIC test on students' language proficiency were analyzed by the independent samples t-test. The pre-test results revealed that there was no statistically significant difference between the two groups $(\mathrm{p}=0.24$, see Table 1$)$, which indicated that both groups were at an identical level prior to the experiment. Both the control group and the experimental group did show an increase on the post-test. However, the results of the post-test did not show a statistically significant difference between the groups ( $\mathrm{p}=0.70$, see Table 2 ). An independent samples $t$-test was also conducted on the means of the gain scores from the pre- and post-test. As indicated in Table 3, there is a statistically significant difference between the two groups. The mean of the gain scores from the control group was 0.67 , and 5.44 from the experimental group. The results indicated that the mean increment from the experimental group was significantly higher than that of the control group.

Table 1. Means comparison of the pre-test

\begin{tabular}{lllllll}
\hline & & Means & SD & t & DF & Sig. (2 tailed) \\
\hline Control Group & $\mathrm{N}=24$ & 55.50 & 10.64 & 1.19 & 47 & 0.24 \\
Experimental Group & $\mathrm{N}=25$ & 51.76 & 11.36 & & & \\
\hline
\end{tabular}
$(\mathrm{P}<0.05)$

Table 2. Means comparison of the post-test

\begin{tabular}{lllllll}
\hline & & Means & SD & t & DF & Sig. (2 tailed) \\
\hline Control Group & $\mathrm{N}=24$ & 56.17 & 9.76 & -0.38 & 47 & 0.70 \\
Experimental Group & $\mathrm{N}=25$ & 57.20 & 9.27 & & & \\
\hline
\end{tabular}
$(\mathrm{P}<0.05)$

Table 3. Means comparison of difference in gain scores on the proficiency test

\begin{tabular}{lllllll}
\hline & & Means & SD & t & DF & Sig. (2 tailed) \\
\hline Control Group & $\mathrm{N}=24$ & 0.67 & 8.86 & -2.14 & 42 & $0.03^{*}$ \\
Experimental Group & $\mathrm{N}=25$ & 5.44 & 6.52 & & & \\
\hline
\end{tabular}

$(\mathrm{P}<0.05)$ 
Because there were two parts of the simulated language proficiency test, the researcher was also interested in exploring the potential impact of extensive reading on vocabulary or grammar skills, or both. Based on the results from the paired-samples t-test, the researcher observed a statistical significant difference on the vocabulary section $(\mathrm{p}=0.00)$, but not on the grammar $(\mathrm{p}=0.46)$. The $\mathrm{t}$-test results were summarized in Table 4 .

Table 4. Means comparison of the gain scores from the experimental group on vocabulary

\begin{tabular}{|c|c|c|c|c|c|c|}
\hline & & Means & SD & $\mathrm{t}$ & DF & Sig. (2 tailed) \\
\hline Pre-test & $\mathrm{N}=25$ & 20 & 6.13 & -3.48 & 24 & $0.00^{*}$ \\
\hline Post-test & & 24 & 4.42 & & & \\
\hline
\end{tabular}

$(\mathrm{P}<0.05)$

Table 5. Means comparison of the gain scores from the experimental group on grammar

\begin{tabular}{|c|c|c|c|c|c|c|}
\hline & & Means & SD & $\mathrm{t}$ & DF & Sig. (2 tailed) \\
\hline Pre-test & $\mathrm{N}=25$ & 31.8 & 6.97 & $\begin{array}{l}-0.74 \\
\end{array}$ & 24 & 0.46 \\
\hline Post-test & & 32.52 & 6.00 & & & \\
\hline
\end{tabular}

$(\mathrm{P}<0.05)$

Other measures were employed to verify the results on language proficiency and to enhance research validity. The researcher also ran a t-test on the students' performance in the class midterm and final vocabulary section. The results show that the two groups didn't show a statistically significant difference in the class midterm vocabulary section. The $t$ value of the t-test between the two groups is 0.30 , and the 2-tailed significance is 0.76 . However, the experimental group scored significantly higher than the control group in the final vocabulary section. The $t$ value of the t-test between the two groups is -2.08 and the 2-tailed significance is 0.04 . There was not a significant gain on vocabulary within the first two months, but a significant gain emerged after about three to four months.

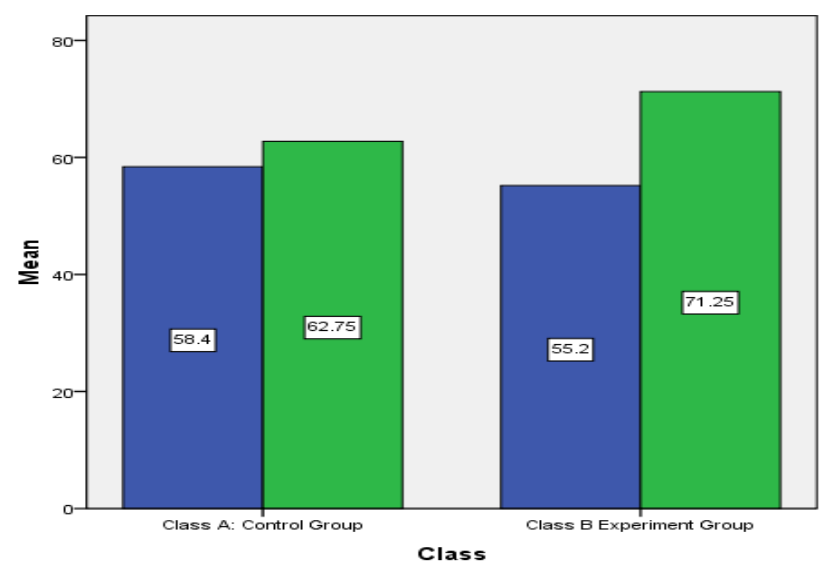
GMidterm Vocabulary
$\square$ Final Vocabulary

Figure 1. Mean scores of the course tests on vocabulary from both groups

As for student participation, the course records showed a statistically significant difference between the control and experimental groups. The researcher offered an extra credit to students who voluntarily spoke during the class time to both groups. The average frequency of the control group was 1.25 times, whereas it was 2.96 times for the experimental group. The results from the course tests and the teacher's observations verified the results from the proficiency test. 


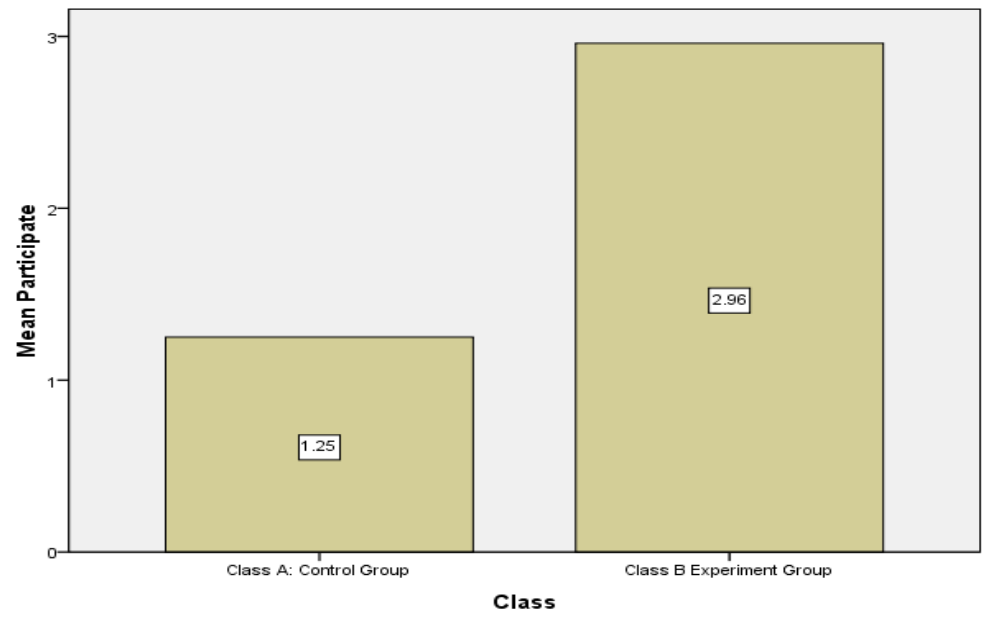

Figure 2. Mean scores of the class participations on from both groups

\section{Results from the Attitudinal Survey}

In terms of the students' opinions on the outside reading materials, students from the experimental group overall manifested positive attitudes toward the extended outside reading materials. According to the attitude survey, the participating students felt that the outside reading materials were relevant to their lives $(M=3.87)$ and helped increase their understanding of the issues $(\mathrm{M}=3.91)$. Most importantly, the materials increased their overall English skills $(M=3.61)$ with a particular improvement in vocabulary $(M=4.13)$ and provided them with materials so that they had more things to say $(M=3.70)$. Most students thought the additional reading enriched their knowledge $(\mathrm{M}=3.91)$ and motivated them to pursue further reading $(\mathrm{M}=3.30)$. Many students would express their opinions in class $(\mathrm{M}=3.17)$, but only a few students would ask questions in class $(\mathrm{M}=2.83)$.

Although the control group was not provided with the outside reading materials, the students were given the survey to find out their general attitudes in regard to outside reading if provided to them. This group of students agreed that outside materials could increase their understanding of issues $(\mathrm{M}=3.73)$ and the materials should be relevant to their lives $(\mathrm{M}=3.92)$. They also believed that outside reading materials could enrich the classroom instructions $(\mathrm{M}=3.62)$. However, their attitudes toward the effects of outside reading materials were not as high as those of the experimental group. The independent-samples t-test showed statistically significant differences between the groups in terms of vocabulary gain $(\mathrm{M}=3.69, \mathrm{t}=2.42, \mathrm{p}=0.02)$, sources for communication $(\mathrm{M}=2.96$, $\mathrm{t}=3.48, \mathrm{p}=0.00)$, motivation for further reading $(\mathrm{M}=2.38, \mathrm{t}=3.74, \mathrm{p}=0.00)$, and expressing opinions in class $(\mathrm{M}=2.15, \mathrm{t}=3.75, \mathrm{p}=0.00)$. It is interesting to note that most students from both groups did not take any initiative to ask questions in class.

The respondents also reported their reading habits and time spent on media. More than $60 \%$ of students from both groups spent more than four hours a week on Chinese reading, but only $34 \%$ from the experimental group spent four hours a week on English and a surprisingly 4\% from the control group spent the same amount on English. Both groups spent a significant time on Internet reading. Close to $60 \%$ of the participants spent more than four hours a week reading Chinese online, but far less time on English, about $8 \%$ for the experimental group and only about $4 \%$ for the control group. Comparing the amount of reading in two languages, the two groups spent a similar amount of time reading in the native language, but students from the experimental group spent significantly more time on class reading and outside reading in English, which may have been a result of the assigned readings. It is interesting to note that over $65 \%$ of the respondents reported more than 4 hours TV viewing time each week. Almost $98 \%$ of the students from the experimental group watched more than 4 movies within the previous six months and about $85 \%$ for the control group. It is apparent that students today spend a significant amount of time watching TV and movies.

\section{Discussion}

The results from the language proficiency test showed that the experimental group that received extended reading materials relevant to the course topics had a much higher gain in the vocabulary component on the language proficiency test. Comparison of students' course exams and class records revealed similar results. 
Iwahori's study (2008) claims that extensive reading helps improve high school students' language proficiency, but cannot pinpoint the specific skills it affects. However, the findings from this present study have provided evidence supporting a positive relationship between extensive reading and vocabulary development. The authentic materials provided an extended exposure to the same topics as in course materials. The repeated exposure in different contexts strengthens students' vocabulary knowledge. An increase of vocabulary is highly correlated with an improvement in reading comprehension (Kirkness \& Neill, 2009). Extensive reading builds up vocabulary knowledge, and an expansion of vocabulary knowledge in return aids greater reading comprehension. But one exposure to a vocabulary word is insufficient to sustain vocabulary knowledge; therefore, continuous exposure to a large quantity of texts is necessary to retain vocabulary and to ensure greater reading comprehension and, therefore, better reading fluency. Although this study demonstrated an increase of vocabulary size from extensive reading, there was not sufficient evidence to establish a relationship between extensive reading and grammar skills. In addition, the results from the attitudinal survey reflected a positive relationship between extensive reading and vocabulary. Students largely thought that the outside reading materials increased their vocabulary and general English ability. Moreover, they were motivated to express their opinions and read further on the issues discussed in the outside materials. These results echoed Wang's findings (2006) on an improvement of communicative competence through extensive reading. In addition to an improvement of language skills, findings also pointed to an increase in students' knowledge of issues and participation in class. All in all, students showed positive attitudes in regard to the extended materials provided to them as outside reading. The class exams and records echoed the results from the proficiency test and the survey, demonstrating that reading is a catalyst for linguistic improvement and reading motivation.

Students' reported habits showed that they spent far more time reading in Chinese than in English, which was to be expected with Chinese being their native language. But the results indicated that these participants spent a significant amount of time on the Internet and mass media, which is congruent with Hendel and Harold's findings (2004) on students' frequent usage of the Internet, and far less time on reading printed materials (Pitcher, Albright, Delaney, et al, 2007). The reason these students spent little time on reading could have been a lack of motivation on required readings or any readings. It could also be a result of flourishing technology and media attraction. The survey results also illustrated a sizable gap between Chinese reading and English reading. The study found that students did have a reading habit in relation to Chinese texts, but students were not as motivated to read English. A better measure needs to be taken to foster students' motivation to read English. These results were similar to the findings in the previous study by the researcher (Guo, 2011) and in Takase's study (2007) on students' leisure reading habits and preferences. In addition, English teachers in Asian contexts are likely to face challenges as they encounter large class sizes, an inflexible syllabus, insufficient class time, and the scarcity of materials. While class time and size may be hard to alter in a short time, teachers could change or supplement materials more easily. Textbooks, especially imported ones, may be too costly to change at once. They could also be limited in scope and presentation of all linguistic aspects in real life language. Because today's students show more interest in online information, teachers could adopt more materials from the Internet. As suggested by Teeler \& Gray (2000), the Internet is a great resource from which teachers can easily find topics and useful language of interest to students. Best of all, a massive numbers of materials can be accessed at no cost. Although many of the authentic materials on the Internet are linguistically demanding, many materials that teachers can choose are suitable for various levels. Teachers need to include students' voices in material selection. In addition to their needs, levels, and interests, text comprehensibility and relevance to students' lives are important factors to assure a positive reading experience.

\section{Conclusion}

This research study examined the effects of extended reading on language proficiency of Taiwanese college students and explored students' attitudes toward the authentic readings utilized as outside reading materials. The study demonstrated a measurable positive effect of extensive reading on students' language acquisition. The findings answered the research questions proposed in this study in regard to the effects of extensive reading on vocabulary and other skills. In particular, the results pointed to significant improvement of vocabulary acquisition, but not grammar. In addition, students experienced gains in knowledge, sources for communication, and other language skills. They also became more involved in class discussions.

This research showed evidence of vocabulary gain and motivation increase as a result of extensive reading of authentic texts. These positive findings were interesting enough to justify an incorporation of extensive in-class or outside-of-class reading activity using authentic materials. Authentic materials expose students to English usage as it is used in real life, thus students may find them more interesting and relevant if they are at the right comprehension level. Reading, an effective practice for vocabulary building, is thus deemed important for both 
reading comprehension and reading fluency. It can serve as a complement to intensive class reading instructions. Extensive reading provides vocabulary not only in a large quantity but also in lexical contexts that are more meaningful to students. The reading also provides a wonderful source of information to expand students' knowledge which otherwise may be limited to course textbooks. A wealth of research has documented the effects of extensive reading including this present study, and several leading researchers believe that extensive reading is one effective way for students to acquire a large vocabulary for reading and language proficiency (Day \& Bamford, 2000; Krashen, 2007; Nation, 2011). Students need a substantial amount of reading to develop language proficiency. For teachers who are concerned about the limited class time, extensive reading can be incorporated as an outside-class activity. This study has presented evidence on a strong relationship between extensive reading and language development, particular in vocabulary. Extended reading can increase not only students' vocabulary size but also promote other aspects of language learning such as motivation.

Despite a strong relationship found between extensive reading and language improvement, this study had several limitations. A study with forty-nine students was small in sample size. Another limitation was that the results came from a homogeneous group of a similar background in culture and learning experiences which limited the generalizability of its findings. Future studies could involve students in a larger group and from more diverse backgrounds. This study investigated the effects of extensive reading mainly on vocabulary acquisition. More research could be conducted to explore the impact of extensive reading on other linguistic aspects such as listening and writing and using other reading formats such as Internet reading.

\section{References}

Anderson, R. C., Wilson, P. T., \& Fielding, L. F. (1988). Growth in reading and how children spend their time outside of school. Reading Research Quarterly, 23, 285-303.

Bahrani, T., \& Sim, T. S. (2011). The role of audiovisual mass media news in language learning. English Language teaching, 4(2), 260-266.

Baleghizadeh, S. (2010). The impact of student-initiated interaction on EFL reading comprehension. Studies in Literature and Language, 1(4), 20-28.

Bell, T. (1998). Extensive reading: Why? and how? The Internet TESL Journal, 6(12). Retrieved from http://iteslj.org/Articles/Bell-Reading.html

Chen, S. Y. (2007). Extracurricular reading habits of college students in Taiwan: Findings from two national surveys. Journal of Adolescent \& Adult Literacy, 50(8), 642-653.

Cummins, J. (2008). Reading and the ESL student. Orbit, 37(2\& 3), 72-75.

Day, R. R. (2011). The benefits of extensive reading. Retrieved from http://www.oup-bookworms.com/downloads/pdf/successful_reading/er_article.pdf

Day, R. R., \& Bamford, J. (2000). Reaching reluctant readers. English Teaching Forum, 38(3). Retrieved from http://eca.state.gov/forum/vols/vol38/no3/p12.htm

Floris, F. (2008). Developing English for general academic purposes (EGAP) course in an Indonesian university. K@ta, 10(1), $\quad 53-62 . \quad$ Retrieved $\quad$ from http://puslit2.petra.ac.id/ejournal/index.php/ing/article/shop/16759/16740

Gilmore, A. (2007). Authentic materials and authenticity in foreign language learning. Language Teach, 40, 97-118.

Golkar, M., \& Yamini, M. (2007). Vocabulary, proficiency, and reading comprehension. The Reading Matrix, $7(3), 88-112$.

Greenberg, D., Rodrigo, V., Berry, A., Brinck, T., \& Joseph, H. (2006). Implementation of an extensive reading program with adult learners. Adult Basic Education, 16(2), 81-97.

Griffiths, G., \& Keohane, K. (2000). Personalizing language learning. Cambridge, UK: Cambridge University Press.

Guo, S. C. (2011). Impact of an out-of-class activity on students' English awareness, vocabulary, and autonomy. Language Education in Asia, 2(2), 246-256.

Guo, S. C. (2011, September). Examining the relationship between outside reading, reading habits, and reading speed. Paper presented at the First Extensive Reading World Congress, Kyoto, Japan.

Hamilton, R. (2010). YouTube for two: online video resources in a student-centered, task-based ESL/EFL 
environment. Contemporary Issues in Education Research, 3(8), 27-31.

Hendel, D. D., \& Harrold, R. D. (2004). Undergraduate student leisure interests over three decades. College Students Journal, 38(4), 557-568.

Hsu, Y. Y., \& Lee, S. Y. (2007). A three-year longitudinal study of in-class sustained silent reading with Taiwanese vocational college students. Selected papers from the Sixteenth International Symposium on English Teaching. Taipei: Crane.

Hsueh-Chao, M. H., \& Nation, P. (2000). Unknown vocabulary density and reading comprehension. Reading in a Foreign Language, 13(1), 403-430. Retrieved from $\mathrm{http}: / /$ nflrc.hawaii.edu/rfl/PastIssues/rfl131hsuehchao.pdf

Huang, C. C. (2005). Effective EFL education through popular authentic materials. Asian EFL Journal, 7(1). Retrieved from http://www.asian-efl-journal.com/March_05_ch.pdf

Huebner, T. A. (2008). Small-group intervention for ELLs. Educational leadership, 66(7), 90-1.

Hunter, A. (2009). Join the literacy club. Principal Leadership, 9(9), 36.

Kazerooni, S. R., Saeedi, M., \& Parvaresh, V. (2011). Does reading literary texts have any impact on EFL learners' vocabulary retention? Canadian Social Science, 7(2), 117-128.

Kirkness, A., \& Neill, L. (2009). Choosing texts for today's students: Do they understand the language? Journal of Hospitality, Leisure, Sport and Tourism Education, 8(2), 4-16.

Krashen, S. (November, 2011). In S. Y. Lee (Moderator), Progress on reading research. Panel discussion conducted at the PAC 2011 and 20th International Symposium and Book Fair on English Teaching, Taipei, Taiwan.

Krashen, S. (2007). Extensive reading in English as a foreign language for adolescents and young adults: A meta analysis. The International Journal of Foreign Language Teaching, 3(2), 23-29.

Krashen, S. (2004). The power of reading (2nd Ed.). Portsmouth, NH: Heinemann.

Krashen, S. (1982). Principles and practice in second language acquisition. Englewood Cliffs, N.J.: Prentice Hall.

Kelly, C., Kelly, L., Offner, M., \& Vorland, B. (2002). Effective ways to use authentic materials with ESL/EFL students. The Internet TESL Journal, 8. Retrieved from http://iteslj.org/Techniques/Kelly-Authentic.html

Lee, S. Y. (2008). Storytelling and sustained silent reading in foreign language acquisition: Evidence from Taiwan. Retrieved from http://www.kzneducation.gov.za/Portals/0/ELITS\%20website\%20Homepage/ IASL\%202008/professional\%20papers/leepp.pdf

Li, C. S., \& Renganathan, S. (2008). Voices of ardent readers: One in concert. The English Teachers, 37, 1-14.

Littlewood, W. T. (1992). Communicative language teaching: An introduction (4th ed.). Cambridge, UK: Cambridge University Press.

Maley, A. (2009). Extensive reading: Why it is good for our students... and for us. Retrieved from http://www.teachingenglish.org.uk/think/articles/extensive-reading-why-it-good-our-students $\% \mathrm{E} 2 \% 80 \% \mathrm{~A} 6$ -us

McNeil, L. (2006). The influence of extensive reading on reading comprehension and reading attitudes. The Korea TESOL Journal, 9(1), 89-107.

Min, H. T., \& Hsu, W. S. (2008). The impact of supplemental reading on vocabulary acquisition and retention with EFL learners in Taiwan. Journal of National Taiwan Normal University, 53(1), 85-115.

Morrow, K. (1977). Authentic texts and ESP. In S. Holden (ed.), English for specific purposes, 13-17. London: Modern English Publications.

Nation, P. (2011). The ten best vocabulary teaching activities. Selected papers for 2011 PAC and the 20th international symposium on English teaching. pp. 140-149. Taipei: Crane Publishing Co. LTD.

Nunan, D. (1999). Second language teaching and learning. Boston, USA: Heinle \& Heinle Publishers.

Pikulski, J. J., \& Chard, D. J. (2005). Fluency: Bridge between decoding and reading comprehension. The Reading Teacher, 58(6), 510-519.

Pitcher, S. M., Albright, L. K., Delaney, C. J., Walter, N. T., Seunarinesingh, K., Mogge, S., Headley, K., 
Ridgeway, V., Peck, S., Hunt, R., \& Dunston, P. (2007). Assessing adolescent's motivation to read. Journal of Adolescent \& Adult Literacy, 50(5), 378-396.

Ponniah, J. (2011). Incidental acquisition of vocabulary by reading. The Reading Matrix, 11(2), 135-139.

Purcell-gates, V., Duke, N. K., \& Martineau, J. A. (2007). Learning to read and write genre-specific text: Roles of authentic experience and explicit teaching. Reading Research Quarterly, 42(1), 8-45.

Sánchez, R. C., Pèrez, A. S., \& Gómes, P. C. (2010). An attempt to elaborate a construct to measure the degree of explicitness and implicitness in ELT materials. International Journal of English Studies, 10(1), 103-129.

Silva, J. P. (2009). Extensive reading through the Internet: Is it worth the while? International Journal of English studies, 9(2), 81-92.

Smith, K. (2007). The effect of adding SSR to regular instruction. Selected papers from the Sixteenth International Symposium on English Teaching. Taipei: Crane.

Soltani, R. (2011). Extensive reading: A stimulant to improve vocabulary knowledge. Studies in Literature and Language, 2(3), 161-167.

Susser, B., \& Robb, T. N. (1990). EFL extensive reading instruction: Research and procedure. JALT Journal, 12(2), 161-185. Retrieved from http://nflrc.hawaii.edu/rfl/October2011/articles/judge.pdf

Takase, A. (2007). Japanese high school students' motivation for extensive L2 reading. Reading in a Foreign Language, 19(1), 1-18.

Teeler, D., \& Gray, P. (2000). How to use the Internet in ELT. Harlow, Essex, UK: Pearson Education Limited.

Therrien, W. J. (2004). Fluency and comprehension gains as a result of repeated reading: A meta-analysis. Remedial and Special Education, 25(4), 252-261.

Tran, A. (2007). A learning-center vocabulary-reading activity for English language learners. The Cleaning House, 81(2), 61-62.

Wang, Y. C. (2006). The impact of extensive reading on communicative competence. Selected papers from the Fifteenth International Symposium on English Teaching. Taipei: Crane.

Wang, W. C., Lin, C. H., \& Lee, C. C. (2011). Thinking of the textbook in the ESL/EFL classroom. English Language Teaching, 4(2), 91-96.

Widdowson, H. G. (1990). Aspects of language teaching. Oxford, UK: Oxford University Press.

Wu, W. C. (2009). Criteria for establishing an authentic EFL learning environment in Taiwan. The Asian EFL Journal, 11(3), 156-189.

Yu, H. C. (2006). A case study in the application of authentic materials texts: findings after using the New York Times Monday weekly on the United Daily News. Canadian Social Science, 2(6), 23-31. 